\title{
MENJADI LESBIAN: \\ KAJIAN INTERAKSIONISME SIMBOLIK \\ LESBIAN DI SURABAYA
}

\author{
Wiwid Megananda \\ Magister Sosiologi, Universitas Airlangga, Surabaya \\ megananda101@gmail.com
}

\begin{abstract}
This article is entitled Becoming Lesbians: A Symbolic Interactionism Study of Lesbian Identity (Case Study in the City of Surabaya). Researchers focus on lesbian individuals not on the lesbian community. The problem raised by the researcher is how the whole process of choosing someone to be a lesbian and the symbols used for interaction with other lesbians. The purpose of this study is to know how a person chooses his life as a lesbian and to find out the symbols used to interact with lesbians. The method used is a qualitative method with a phenomenological approach. In this study informants numbered four people and all four occupy their respective roles in lesbians. From the results of this study there are several reasons why someone chooses to become a lesbian: social profiles, her-story, lesbian firts time, what changes, reactions and what next. From these concepts, the conclusion is that family background does not influence a person to become a lesbian, but rather from personal experiences in the past or experiences with social relations.
\end{abstract}

Keyword: lesbian, lesbian symbol, interaksionisme simbolik, gender

\begin{abstract}
Abstrak
Artikel ini berjudul Menjadi Lesbian: Kajian Interaksionisme Simbolik Identitas Diri Lesbian (Studi Kasus Di Kota Surabaya). Peneliti berfokus kepada individu lesbian bukan pada komunitas lesbian. Adapun masalah yang diangkat oleh peneliti adalah bagaimana proses keseluruhan seseorang memilih hidup menjadi lesbian beserta simbol-simbol yang digunakan untuk interaksi sesama lesbian. Tujuan dari penelitian ini yaitu untuk mengetahui bagaimana proses seseorang memilih hidupnya sebagai lesbian dan untuk mengetahui simbol-simbol yang
\end{abstract}


digunakan untuk berinteraksi sesama lesbian. Metode yang digunakan adalah metode kualitatif dengan pendekatan fenomenologi. Dalam penelitian ini informan berjumlah empat orang dan keempat orang tersebut menduduki peran masing-masing sebagai seorang lesbian. Dari hasil penelitian ini terdapat beberapa alasan mengapa seseorang memilih menjadi lesbian: profil sosial, her-story, firts time lesbian, apa yang berubah, reaksi dan what next. Dari beberapa konsep tersebut kesimpulannya bahwa latar belakang keluarga tidak terlalu mempengaruhi keputusan seseorang menjadi lesbian, melainkan dari pengalaman pribadi pada masa lampau maupun pengalaman dengan pergaulan sekitar.

Kata Kunci: lesbian, simbol-simbol lesbian, interaksionisme simbolik, gender

\section{PENDAHULUAN}

Lesbian adalah istilah perempuan yang mengarahkan orientasi seksualnya kepada sesama perempuan atau disebut juga perempuan yang mencintai perempuan baik secara fisik, seksual, emosional atau secara spiritual. Lesbian juga adalah seorang perempuan yang memiliki ikatan emosional-erotis dan seksual terutama dengan perempuan atau yang melihat dirinya sebagai bagian dari sebuah komunitas yang mengidentifikasikan diri sebagai lesbian (Adhiati, 2007: 26).

Sebagian kota besar di Indonesia yang memiliki beragam masyarakat menganut gaya hidup bermacammacam. Tidak dapat dipungkiri, komunitas gay dan lesbian telah hadir di dalam masyarakat. Komunitas gay dan lesbian dapat dikatakan sebagai penganut paham liberalisme hedonis (paham keduniawian). Dikatakan seperti itu karena dulu biasanya lebih mudah menemukan komunitas gay dan lesbian di tempat-tempat hiburan malam. Sebagai contoh adalah gaya hidup mereka yang kini dapat ditemukan di klub-klub malam yang menjadi wadah tempat pertemuan mereka.
Hal seperti itu sudah sangat lumrah dan dianggap tidak tabu lagioleh sebagian besar kaum gay dan lesbian tersebut, sehingga mereka menjadi lebih mudah untuk menjalin ikatan antar sesama. Namun kali ini tidak hanya di tempat hiburan malam atau tempat tertutup, mereka sering kali hadir dan membaur dengan masyarakat seperti di tempattempat yang umum dijadikan sebagai pusat aktivitas melepaskan kepenatan masyarakat, yaitu kafe, mall atau plaza (Majalah Bisnis Indonesia, 2003: 79).

Peneliti melakukan penelitian tentang menjadi lesbian untuk mengetahui proses mereka menjadi lesbian dan ditinjau lebih dalam lagi dari sisi sosiologis. Di dalamnya banyak konsep yang ditemukan peneliti dalam proses observasi maupun penelitian dan hal tersebut membedakan penelitian ini dengan penelitian lesbian pada umumnya.

\section{METODE}

Pendekatan

penelitian yang dipakai penulis adalah pendekatan fenomenologi. Fenomenologi ini berasal dari filsafat yng mengelilingi kesadaran manusia yang dicetuskan oleh 
Edmund Husserl (1859-1938) seorang filsuf Jerman. Fenomenologi itu sendiri adalah pendekatan yang dimulai oleh Edmund Husserl dan dikembangkan oleh Martin Heidegger untuk memahami atau mempelajari pengalaman hidup manusia. Pendekatan ini berevolusi sebuah metode kualitatif yang matang dan dewasa selama beberapa dekade pada abad ke 20.

Fokus umum penelitian ini untuk memeriksa/meneliti esensi atau struktur pengalaman ke dalam kesadaran manusia. (Tuffour, 2017). Alasan peneliti menggunakan pendekatan tersebut karena ingin mendalami bagaimana seorang lesbian memutuskan sebuah pilihan yaitu menjadi seorang lesbian.

Adapun subjek penelitian selaku informan dalam penelitian ini adalah perempuan lesbian yang berperan sebagai Butchi dan Femme. Sedangkan informan pendukung merupakan penjaga stand di Royal Plasa Surabaya. Pemilihan informan utama diseleksi kembali untuk pemilihan informan kunci yang dianggap mempunyai kredibilitas informasi dan pengalaman hidup yang bisa dibagikan kepada peneliti. Informan kunci yaitu mereka yang mengetahui dan memiliki berbagai informasi pokok yang diperlukan dalam penelitian, informan utama yaitu mereka yang terlibat langsung dalam interaksi sosial yang diteliti. Sedangkan, informan tambahan yaitu mereka yang dapat memberikan informasi walaupun tidak langsung terlibat dalam interaksi sosial (Suyanto dan Sutinah, 2008: 172). Informan dalam penelitian ini berjumlah 4 orang lesbian.

Pengumpulan data primer diperoleh dengan interview guide dimana umumnya berisi tentang pertanyaan yang bersifat terbuka dan ingin memperoleh jawaban yang mendalam. Rangkaian pertanyaan yang tersusun dalam interview guide tidak dilengkapi dengan option jawaban yang sudah ditentukan terlebih dahulu, tetapi jawaban yang dikehendaki seluas, terperinci, dan selengkap mungkin.

Datalapanganyangsudahterkumpul selanjutnya dikategorikan, diklasifikasi, diinterpretasi, dan kemudian dianalisis. Analisis digunakan dengan memakai konsep-konsep dari berbagai pandangan yang tersusun dalam kerangka toeri sehingga akhirnya mampu menciptakan kesimpulan sesuai dengan keadaan yang sebenarnya yang terjadi di lapangan

\section{HASIL DAN PEMBAHASAN}

Penelitian ini memiliki empat informan. Keempat informan tersebut bernama samaran. Kondisi sosial ekonomi dari empat informan tersebut termasuk ke dalam middle class. Berikut adalah kutipan wawancara dengan informan yang menggunakan nama Inisial asli bukan samaran.

Informan pertama bernama VR. VR merupakan anak pertama dari dua bersaudara,VR mempunyai adik seorang perempuan. VR sekarang berusia 25 tahun, informan tersebut sekarang menempuh kuliah di salah satu universitas negeri di Madura. Keseharian VR bekerja sebagai salah satu pemain organ di beberapa orkes. Informan tersebut bertempat tinggal di salah satu desa di Sidoarjo. VR tidak menyebutkan nama desanya dikarenakan alasan privasi. Kondisi sosial ekonomi VR dapat dikategorikan cukup meskipun orang tuanya bekerja sebagai petani tetapi mereka mempunyai lahan sendiri. 
Sedangkan ibu VR bekerja sebagai pedagang kue tetapi tidak menjadikan aktivitas utama untuk berdagang kue melainkan jika ada pesanan saja. Dalam lingkungan masyarakat meskipun orang tua VR bekerja sebagai petani keluarga VR sangat disegani oleh masyarakat dikarenakan ayah dari VR adalah seorang Modin desa yang biasanya menjadi imam di masjid.

Dari temuan data di lapangan menjelaskan tentang bagaimana keluarga informan disegani dalam masyarakat karena ayah informan menjadi salah satu tokoh dalam masyarakat dan terkenal religius di lingkungannya. Kondisi tersebut tidak mempengaruhi informan untuk memilih pilihan hidupnya menjadi penyuka sesama jenis perempuan. Dari hasil wawancara peneliti terhadap VR di dalam anggota keluarga maupun saudara menurut informan tidak ada yang menyukai sesama jenis hanya informan saja yang menyukai sesama jenis.

Informan kedua bernama IN, merupakan anak ketiga dari tiga bersaudara. Keseharian IN adalah mahasiswa di salah satu universitas di Malang. IN sekarang berusia 22 tahun. IN bertempat tinggal di kota Surabaya, IN tidak menyebutkan alamat asal karena alasan privasi. Kondisi sosial ekonomi keluarga IN dapat dikategorikan menengah ke atas menurut informasi yang diberikan informan ayah informan bekerja di salah satu instansi di kota Surabaya sedangkan ibu informan bekerja di salah satu SMA di Surabaya menjadi guru keduanya sudah PNS. Keluarga IN merupakan keluarga dengan kondisi ekonomi cukup baik dikarenakan pekerjaan orang tua yang sudah mapan. Image keluarga IN dalam masyarakat cukup baik yaitu berpendidikan dan masyarakat sangat segan kepada keluarga IN. Menurut IN salah satu dari anggota keluarga yaitu kaka lakilaki adalah seorang gay. Berikut adalah kutipan wawancara terhadap IN:

“Ada, kakak saya yang laki-laki dia penyuka sesama jenis (gay) tetapi kakak saya tidak letoi kakak saya macho dan baik. Awal mulanya saya tidak mengetahui kalau kakak saya adalah penyuka sesama jenis tetapi saya tau gara-gara sudah dekat sekali dengan kakak saya. Kakak saya cerita sendiri dan pengalamanpengalamanya akhirnya saya menjadi pendengar yang baik untuk kakak saya jadi teman curhat di keluarga karena di dalam keluarga saya adalah salah satunya yang mengetahui kalau kakak saya adalah penyuka sesama jenis."

Dalam penjelasan tersebut informan dan Kakak informan hubungan kekeluargaan sangat dekat karena tempat berkeluh kesah dalam keluarga yang pertama adalah IN begitupun sebaliknya.

Informan ketiga bernama LK, merupakan anak kedua dari tiga bersaudara. LK merupakan satu-satunya perempuankeduasaudaranyaadalahlakilaki. Kakaknya sudah bekerja sedangkan adiknya masih SMA. LK berusia 24 tahun keseharian bekerja sambil kuliah di salah satu universitas di Surabaya. LK berasal dari kota Bojonegoro tetapi LK tidak menyebutkan desanya dikarenakan alasan privasi. Ayah LK bekerja sebagai tenaga serabutan apapun dikerjakan asalkan halal untuk keluarga, sedangkan keseharian ibu LK bekerja sebagai petani 
terkadang juga menjadi buruh tani, tetapi keluarga LK sudah mempunyai lahan pertanian sendiri tanpa menyewa.

Dari penjelasan LK kondisi sosial ekonomi di lingkungan sekitar adalah menengah kebawah. Keluarga LK tidak mempunyai peranan penting dalam masyarakat misalnya bekerja di aparatur desa. Keluarganya hanya berasal dari keluarga sederhana. Keseharian LK selain kuliah yaitu bekerja untuk memenuhi kebutuhan sehari-hari tanpa merepotkan orang tua. Selain untuk kebutuhan sehari-hari LK terkadang juga membiayai adiknya. Berikut adalah kutipan wawancara informan LK:

"Saya sendiri masih kuliah tetapi saya juga bekerja untuk memenuhi kebutuhan saya sehari-hari, terkadang adik saya juga minta uang jajan kepada saya."

Menurut hasil wawancara dari informan tidak ada keluarga yang penyuka sesama jenis kecuali LK.

Informan ke empat bernama TJ, merupakan anak pertama dari dua bersaudara. TJ mempunyai adik perempuan yang masih duduk di bangku SMP. TJ sekarang berusia 26 tahun. Ayah TJ kesehariannya adalah bekerja sebagai aparatur desa yaitu sebagai wakil kepala desa serta salah satu anggota takmir masjid. Biasanya juga dipanggil untuk mewakili desanya untuk keperluan penyerahan pengantin. Sedangkan ibu TJ kesehariannya adalah selain menjadi ibu wakil kepala desa, ibu TJ juga menjabat sebagai ibu-ibu PKK dalam desanya. TJ bertempat tinggal di kabupaten Jombang tetapi tinggal di desa. Nama desa tidak disebutkan oleh informan dikarenakan alasan privasi. Keseharian TJ tinggal di salah satu pesantren di kota Surabaya. Kondisi sosial ekonomi dalam lingkungan keluarga TJ termasuk keluarga yang mempunyai image baik dan termasuk keluarga berada karena peran penting dalam desa kedua orang tuanya mempunyai wibawa tersendiri dan di segani dalam lingkungannya. Keluarga TJ merupakan keluarga yang harmonis dan menurut pengakuan TJ di dalam keluarga maupun saudara tidak ada yang menyukai sesama jenis.

\subsection{Proses Seseorang Menjadi Lesbian}

Informan pertama adalah berinisial VR, VR menyadari pada saat pertama kali tertarik terhadap perempuan pada saat merasa tidak percaya lagi terhadap laki-laki karena mempunyai pengalaman yang kurang baik terhadap mantan pacar pada waktu SMA. Pada saat tersebut VR sangat terpuruk karena VR sudah menaruh harapan besar terhadap pacarnya untuk melanjutkan ke jenjang yang lebih serius setelah lulus SMA tetapi harapan tersebut kandas dan membuat VR merasa stress akan jalan hidup selanjutnya.

Informan kedua adalah berinisial IN, faktor keluarga yang melatarbelakangi awal mulanya IN tertarik terhadap perempuan. Saudara kandung, kakak dari IN adalah seorang gay, mereka dalam keluarga dapat dikatakan sangat dekat karena semua masalah apapun yang di hadapi baik kakak maupun adik biasanya saling cerita dan terbuka. Ketertarikan IN terhadap perempuan bukan dilatar belakangi oleh pengalaman buruk melainkan dari ketertarikan kakak IN yang sering cerita dan terbuka 
akhirnya secara tidak sadarkan diri IN tertarik terhadap salah satu taman dari kakaknya. Awal mulanya hanya sekedar kagum tapi lama-kelamaan IN tertarik terhadap perempuan tersebut.

Ketertarikan IN terhadap sesama jenis pada saat IN mulai perkenalan dengan teman dari kakak IN. Pada saat pertama kali kenal IN sudah merasa tertarik tetapi tidak berfikir panjang dan IN berfikir bahwa itu hanya kagum saja. Akan tetapi IN semakin hari, semakin berfikir bahwa rasanya melebihi kagum dan mulai mendekati dengan cara jalanjalan. Berikut adalah kutipan wawancara peneliti dengan informan IN:

"Saya menyadari hal tersebut pada saat saya sering diajak curhat sama kakak saya, dan mulailah bergabung dengan aktivitas dan teman-teman dari kakak saya pada saat itu kakak saya mengenalkan temantemannya ke saya dan pada saat itu saya entah gak tau kenapa tiba-tiba tertarik terhadap perempuan yang bersama kakak saya. Awalnya saya tidak menhiraukan perasan saya mungkin saya hanya kagum karena perempuan tersebut berpenampilan seperti laki-laki dan terlihat ganteng serta mnyenangkan tetapi perasaan itu tumbuh dan malah bikin saya tidak tertarik terhadap laki-laki. Berminggu minggu saya terpikirkan perempuan tomboy tersebut akhirnya saya chatingan dan kenalan, jalan, makan bareng pada saat itu saya menyadari bahwa perasaan saya melibihi teman atau bisa disebut saya mulai ada ketertarikan kepada perempuan tersebut."
Informan ketiga berinisial LK. LK menyadari bahwa mulai menyukai sesama jenis perempuan pada saat sering mengikuti komunitas temannya. LK memiliki teman yang penyuka sesama jenis perempuan. Kebetulan LK sering mengikuti kegiatan misalnya kumpulkumpul di salah satu mall di Surabaya. Alasan LK menyukai sesama jenis perempuan yaitu bosan dengan hidup dan dalam keluarga juga mempunyai masalah sehingga LK memilih untuk jalan seperti ini. Pada awal mulanya LK memang mempunyai pacar laki-laki tetapi frustasi karena kedua orang tua LK yang menyuruh LK untuk melanjutkan hubungan yang serius dengan lakilaki yang kaya dan mapan sedangkan LK sudah terlanjur menyanyangi pasangannya tersebut.

Awal ketertarikan LK terhadap sesama jenis perempuan yaitu kepada teman LK pada saat menghadiri agenda mingguan oleh komunitas lesbian tersebut. Pada saat itu LK hanya mencari kesenangan dan kumpul-kumpul supaya ada aktivitas lain akan tetapi lama kelamaan LK tertarik dan merasa senang layaknya jatuh cinta terhadap laki-laki akhirnya menjalin hubungan dengan perempuan tersebut.

Informan keempat adalah TJ. TJ menyadari bahwa dirinya mulai suka terhadap sesama jenis adalah pada saat di pesantren. Alasannya adalah selain mayoritas teman dekatnya adalah perempuan, kondisi keluarganya juga over protektif terhadap pergaulan lawan jenis bahkan hampir tidak mendapatkan ijin untuk keluar dengan laki-laki sebelum menjadi suami. Pada akhirnya TJ memutuskan daripada menyakiti hati orang tua jika terus berhubungan 
dengan laki-laki maka TJ memilih untuk mendekati perempuan untuk dijadikan kekasih. TJ bisa mendapatkan kebahagian tanpa membuat rasa khawatir orang tuanya terhadap TJ berlebihan. Selain itu juga TJ mendapat kebebasan keluar kemanapun dan mencari kesenangan dengan bebas.

Pada awal TJ merasa tertarik terhadap perempuan adalah jatuh cinta terhadap teman yang berada di pesantren yang sama. Perasaan tersebut menurut TJ sudah ada sejak lama tetapi TJ tidak memperdulikan perasaannya tersbut akan tetapi lama-kelamaan TJ tertarik dengan perempuan tersebut yang awalnya hanya teman curhat tetapi berubah menjadi rasa kangen, rasa sayang dan ingin memiliki. Perempuan tersebut menurut TJ sudah sejak lama menyukai perempuan, TJ adalah tempat curhat perempuan tersebut awalnya seperti itu dan akhirnya jatuh cinta dan menjalin hubungan berpacaran, rasanya seperti jatuh cinta secara normal bedanya hanya TJ menyukai sesama jenis perempuan.

\subsection{First Time Lesbian}

Informan pertama berinisial VR. Pada awal kejadian VR menyukai sesama jenis perempuan adalah menyangkut pengalaman masa lalu VR yang kurang baik. Dulu pada saat VR masih duduk di bangku SMA VR mempunyai pasangan yang dianggapnya serius dan mau melanjutkan ke hubungan yang lebih serius, pada saat itu pasangan VR sudah sering berkunjung ke rumah VR dan sudah membicarakan tentang hal yang lebih serius tentang hubungannya mereka. Akan tetapi VR merasa kecewa VR dikhianati dan merasa frustasi. Untuk mengenal laki-laki saja VR sudah tidak mau lagi karena sudah terlanjur kecewa. Seketika itu harapan VR pupus.

Setelah setahun lamanya VR tidak memiliki pacar, VR bertemu dengan perempuan tersebut sudah sejak lama, VR juga menyadari bahwa teman perempuannya adalah seorang lesbian tetapi masih mempunyai pasangan lakilaki. Berikut adalah kutipan waancara peneliti dengan informan VR:

"Kami sudah lumayan lama berhubungan tetapi karena dia punya pacar laki-laki akhirnya kita berantem dan putus ditengah jalan, tetapi masih berhubungan meskipun saya tau bahwa dia punya pasangan laki-laki tapi dia juga sudah ketergantungan dengan saya dan tidak mau hubungan berakhir begitu saja. Akhirnya dia mutusin pacarnya dan masih sama jalan sama saya."

Pada saat VR mengungkapkan perasaan sebenarnya terhadap perempuan tersebut VR lebih memilih memperhatikan gerak gerik perempuan tesebut ternyata perempuan tersebut lebih menunjukkan terlebih dahulu dan akhirnya saling mengungkapkan dan saling menyukai akhirnya mereka menjalin hubungan.

Informan kedua adalah IN. Pada awal kejadian IN menyukai sesama jenis perempuan adalah bukan tentang permasalahan di masa lalu. IN juga terlahir dari keluarga yang berada dan keluarga yang harmonis. Awal mulanya IN menyadari bahwa IN menyukai sesama jenis perempuan yaitu pada saat IN berkenalan dengan salah satu teman perempuan dari kakak IN. Perasaan IN 
pada saat itu rasanya seperti IN jatuh cinta terhadap laki-laki, kebetulan kakak IN sering bercerita tentang dirinya bahwa dirinya adalah gay. Dari situlah IN merasakan perasaan jatuh cinta terhadap perempuan.

Pada saat proses pendekatan IN, IN lebih dominan dari pada perempuan yang di suka oleh IN pada saat itu IN lebih sering menghubungi perempuan yang bersangkutan untuk sekedar bersapa lewat sosial media atau bertemu langsung. IN menyadari bahwa perempuantersebutjuga tertarik terhadap dirinya akhirnya IN memberanikan diri untuk mengungkapkan perasaaan yang dialaminya selama ini dan pada akhirnya mereka setuju untuk melanjutkan hubungan yang lebih dari seorang teman. Berikut adalah kutipan hasil wawancara peneliti dengan informan yang berinisial IN:

“Tetapi saya tidak seperti itu perasaan tersebut timbul begitu saja ketika dia dekat dengan temantemanya dikampus saya mulai cemburu, setiap hari rasanya ingin bertemu dan selalu chatingan dan terus $\mathrm{ku}$ telfon dia seperti itu rasanya. Awalnya juga saya tidak tahu kalau ternyata perempuan yang saya suka dia sudah lama menyukai perempuan akhirnya saya berani cerita kalau saya tertarik sama dia dan diapun membalas perasaan saya."

Ketika IN menceritakan tentang perasaan teesebut terhadap perempuan yang bersangkutan ternyata perempuan tersebut mengaku bahwa ia sudah lama menjadi penyuka sesama jenis perempan.
Perasaan IN yang dirasakan pada saat jatuh cinta terhadap sesama lesbian, IN merasa senang dan nyaman.

Informan ketiga yaitu LK. Pada awal kejadian ketika LK menjadi penyuka sesama jenis perempuan adalah faktor keluarga, pada usia muda dulu LK sudah mempunyai pasangan laki-laki. Hubungan mereka sudah berjalan sejak lama akan tetapi hubungan tersebut tiba-tiba selesai di tengah jalan akibat tidak mendapatkan restu dari orang tua. Alasan orang tua LK tidak tidak merestui anaknya untuk menjalin hubungan dengan laki-laki tersebut ialah faktor pekerjaan yang kurang pantas unntuk anaknya. Akhirnya LK mulai bosan dengan hidupnya dan selama sendiri LK sering mengikuti kegiatan kumpul bersama komunitas leasbian.

Dari situ LK mulai tertarik dengan perempuan, pada saat itu LK merasa tertarik terhadap perempuan yang menurutnya berkharisma dan mempunyai daya tarik tersendiri. Awal mulai LK menjalin hubungan dengan perempuan tersebut LK merasa jatuh cinta terlebih dahulu dan akhirnya LK mengungkapkan perasaannya, karena sering sekali bertemu di agenda mingguan mereka mulai saling cerita dan merasa nyambung pembicaraannya akhirnya mereka menjalin hubungan. Berikut adalah kutipan wawancara peneliti dengan informan yang berinisal LK:

"Saya sering berkumpul dengan orang-orang penyuka sesama jenis perempuan dan tiba-tiba saya nyaman, saya nyambung dalam segala hal, dia mengerti akhirnya saya jadian dengan salah satu dari 
mereka dan saya merasa senang dan bahagia sampai saat ini."

Pada saat LK menjalin hubungan dengan perempuan, LK merasa sangat senang dan tidak ada beban apapun dalam hidupnya.

Informan keempat adalah TJ. Awal mula TJ menyukai sesama jenis perempuan dikarenakan kedua orang tua yang over protektif terhadap TJ. Kebebasan adalah aktor utama yang melatarbelakangi TJ menjadi seperti itu. Awal mula TJ menyukai sesama lesbian pada saat TJ sering sekali menjadi teman curhat orang tersebut, orang tersebut sudah lama menjadi lesbian. Pada saat itu TJ masih belum tertarik dan perasaannya masih biasa saja terhadap perempuan, tetapi ketika sering jalan sering curhat dan nyambung dalam cerita akhirnya TJ tiba-tiba merasa jatuh cinta terhadap orang tersebut.

Pada saat TJ mengungkapkan perasaan tersebut orang yang bersangkutan ternayata juga merasakan perasaan yang sama. Pada saat itu TJ merasa senang dan sangat bahagia mendengar ucapan orang tersebut. Akhirnya mereka menjalani hubungan selayaknya pacar. Berikut adalah kutipan wawancara peneliti terhadap informan yang berinisial TJ:

"Kejadian awal pada saat saya menyukai sesama jenis perempuan pada saat saya sering curhat dan jalan-jalan dengan teman perempuan saya. Pada saat itu saat merasa nyaman dan bahagia akhirnya jatuh cinta, diapun juga respek sama saya. Tetapi dia sudah lama menyukai sesama perempuan, dulu juga sering curhat sama saya tentang pasanganya. Tetapi pada saat itu saya belum menyukai sesama perempuan. Dan selang beberapa bulan dia kaya ada kharismatik, seperti laki-laki dan tidak tau kenapa saya tiba-tiba naksir sama dia."

Kehidupan subjek penelitian didasarkan pada identitas determinan sosial dari hubungan, jaringan lesbian dan pembentukan komunitas. Setelah subjek memutuskan untuk sebagai seorang lesbian, maka dalam melakukan relasi seksual dengan sesama perempuan akan menjalankan posisi sebagai butchy (berposisi sebagai maskulin) dan femme (berposisi sebagai feminin).

Dari hasil penelitian, keempat informan memiliki pengalaman pribadi yang berbeda dan proses pembentukan diri menjadi lesbian yang juga berbeda. Faktor keluarga salah satunya akibat terbatasnya pergaulan dengan lawan jenis akhirnya memilih pilihan hidup menjadi lesbian akibat sering bergaul dengan sesama jenis. Pengalaman traumatik juga menjadi salah satu alasan informan kedua untuk memilih hidupnya menjadi lesbian karena rasa kecewalah yang mendasari kebencian terhadap laki-laki. Selain itu juga faktor genetik dari keluarga juga dapat membangkitkan gairah seseorang sehingga mengikuti jejak keluarga dan memilik menjadi lesbian, berikut adalah analisi menggunakan teori interaksionisme simbolik.

Pemaknaan diri subjek penelitian sebagai subjek sebagai lesbian adalah bagaimana subjek penelitian menilai, memperlakukan diri dan memandang dirinya sebagai seorang lesbian dalam kaitannya dengan kehidupan pribadi dan sosialnya. Pada teori interaksionisme 
simbolik Blummer (1998) terdapat salah satu konsep yang berkaitan dengan diri (self). Self hadir dari kelahiran secara alami dan tidak dapat diacuhkan koswensinya pada perkembangan individu secara biologi. Melainkan individu belajar tentang dirinya dirinya melalui interaksi ini seseorang menjadi percaya bahwa dia berbeda dari orang lain dan mempunyai arti. Sangatlah penting pengenalan diri sendiri menjadi dasar dalam interaksi sosial.

Blummer merujuk pada karakter interaksi yang berlangsung antar manusia. Aktor tidak semata-mata bereaksi terhadap tindakan yang lain, akan tetapi dia menafsirkan dan mendefinisikan setiap tindakan orang lain. Respon aktor baik secara langsung maupun tidak langsung selalu didasarkan atas penilaian tersebut. Oleh karenanya, interaksi manusia dijembatani oleh beberapa simbol penafsiran atau dengan menemukan makna tindakan orang lain (Zeitlin, 1995).

Konsep diri adalah semua ide, pikiran, kerpercayaan dan pendirian yang diketahui individu tentang dirinya dan mempengaruhi individu dalam berhubungan dengan orang lain. Konsep diri juga diartikan sebagai kesadaran batin yang tetap, mengenai pengalaman yang berhubungan dengan "aku" dan membedakan "aku dari yang bukan "aku" (Blummer, 1998). Dari hasil penelitian ini diketahui bahwa pemaknaan diri subjek penelitian sebagai lesbian cukup beragam. Terdapat 4 variasi yang menunjukkan penerimaan diri subjek, pengalaman traumatik dalam masa lalu, faktor biologis, dan rasa kecewa karena tidak mendapat restu orang tua dari hubungannya pada masa lalu.
Dari hasil penelitian dapat disimpulkan bahwa lesbian yang memaknai dirinya sebagai pribadi yang tidak diharapkan yang diungkapkan dari rasa kecewa, amarah akan rasa traumatik cenderung memliki kehidupan yang lebih tertutup dan sulit bersosialisasi serta terlebih dalam mengungkapkan identitas yang sebenarnya sebagai seorang lesbian. Berbeda dengan yang memaknai dirinya atas dasar faktor bilogis individu tersebut cenderung tanpa beban dalam bersosialisasi cenderung dengan masyarakat serta cenderung terbuka terhadap identitasnya sebagai lesbian.

Masing-masing informan menemukan identitas diri mereka dengan tahapan tindakan melalui interaksi simbolik yang disampaikannya melalui beberapa tahapan impuls, persepsi, manipulasi, dan konsumasi yang disampaikannya. Selanjutnya rangsangan informasi tersebut dapat dipahami menjadi sebuah persepsi. Dalam persepsi tersebut, informasi yang diterima tidak langsung diterima begitu saja, ada beberapa faktor yang sangat mempengaruhi, yaitu pengalaman dan peristiwa yang terjadi dalam latar belakang informan yang selanjutnya diseputar informasi yang diterima dengan beberapa peristiwa lainnya yang berhubungan setelah mengalami beberapa peristiwa tersebut. Jadi, dari masing-masing latar belakang informan menjadi seorang lesbian tentunya berbeda.

\subsection{Simbol Interaksi Melalui Penampilan Fisik}

Ada beberapa simbol yang ditunjukkan yang menunjukkan bahwa simbol yang dipakai tersebut khusus 
untuk para lesbian. Namun simbol tersebut dipakai hanya pada kalangan lesbian yang berperan sebagai butchi, melalui pemberian simbol-simbol yang ditunjukkan oleh para lesbian tersebut merupakan salah satu isyarat yang digunakan kelompok lesbian untuk mengungkapkan identitas dirinya bahwa ia adalah seorang lesbian.

Dapat dilihat ketika para lesbian menggunakan penampilan yang menunjukkan isyarat atau ciri-ciri khusus seperti tindik hitam di telinga kiri serta selalu memakai kemeja atau kaos bewarna hitam, memakai cincin di jari manis kiri dan ketika memegang cangkir jari kelingking mereka diberdirikan adalah salah satu simbol yang menunjukkan bahwa mereka adalah seorang lesbian. Selain dari penampilan juga dapat dilihat dari bahasa-bahasa tertentu yang mana hanya kelompok lesbian tersebut yang mengatahuinya. Namun simbol tersebut hanya digunakan oleh kelompok butchi.

Simbol interaksi melalui bahasa, sikap ataupun perilaku isyarat suara sangat penting perannya dalam pengambangan yang signifikan. Fungsi bahasa atau simbol yang digunakan yaang signifikan pada umumnya adaalah menggerakkan tanggapan yang sama di pihak individu yang berbicara dan juga pihak lainnya. Kumpulan isyarat suara yang paling mungkin menjadi simbol yang signifikan adalah suara karena pada suara simbol yang yang menjawab makna yang dialami individu pertama dan yang mencari makna kedua. Isyarat suara yang mencapai situasi seperti itulah yang dapat disebut sebagai simbol bahasa.

Bahasa sebagai sistem yang sangat luas dan kata-kata adalah simbol yang digunakan untuk menggantikan sesuatu yang lain. Dari semua informan lesbian ini mempunyai simbol bahasa tersendiri. Kata-kata yang digunakan para kelompok lesbian tersebut hanya diketahi oleh orang yang bersangkutan yaitu lesbian itu sendiri.

Namun tidak semua bahasa lesbian yang semuanya diketahui oleh para lesbian. Simbol merupakan sesuatu yang disepakati bersama. Hal itupun yang dialami oleh berbagai kelompok lesbian. Ada beberapa bahasa yang para lesbian tidak ketahui dikarenakan mereka berasal dari komunitas yang berbeda. Bahasa tersebut mempunyai makna yang berbeda jika mungkin diartikan dalam Bahasa Indonesia yang sebenarnya.

Hal itu bertujuan agar dapat digunakan pada situasi tertentu yang mana jika kelompok lesbian tersebut sedang berkumpul dan ada outsider atau orang lain yang datang yang merupakan non lesbian maka mereka akan menggunakan simbol bahasa tersebut. Contoh bahasa-bahasa tersebut adalah L, belok, line, beb, pem, GF, lurus, no label, double, linak, American style, pecongan. $\mathrm{L}$, line dan belok yang merupakan persamaan lesbian. Beb adalah Butchi atau yang berperan sebagai laki-laki dalam hubungan lesbian. Pem merupakan Femme atau yang berperan sebagai perempuan dalam hubungan lesbian. GF merupakan pasangan/pacar lesbian. Lurus merupakan wanita heteroseksual. No label lesbian yang tidak masuk dalam kategori. Double adalah dua pasangan lesbian yang sedang berpacaran. Linak merupakan laki-laki heteroseksual. Pecongan merupakan pasangan lesbian yang sedang berpacaran.

Selain itu terdapat pula sikap isyarat atau gesture yang mana merupakan 
salah satu mekanisme tindakan dalam proses menjalani perannya sebagai seorang lesbian. Sebagai seorang lesbian ia akan mempunyai sikap atau perilaku yang memiliki perbedaan dengan wanita lainnya. Contoh perilaku tersebut adalah memberi tatapan, perhatian yang lebih pada wanita dan berusaha mendekati perempuan yang dia sukai. Seorang lesbian akan memperlihatkan ketertarikannya pada wanita yang ia sukai layaknya wanita heteroseksual.

\subsection{Penerapan Simbol-Simbol Interaksi Kaum Lesbian}

Simbol-simbol yang mereka gunakan tersebut baik dari simbol verbal maupun non verbal digunakan sesuai peran mereka masing-masing. Seorang lesbian butchi, femme, ataupun andro. Peran yang mereka ambil sesuai dengan konsep diri yang ada pada diri mereka dan sesuai menurut teori Mead yaitu Mind (Pikiran) dan Self (Diri). Para informan memilih menjadi seorang lesbian karena mempunyai dorongan perasaan terhadap wanita dan melihat pengalaman mereka. Tidak semua informan menunjukkan bahwa mereka adalah seorang lesbian. Beberapa informan hanya menunjukkan ke beberapa orang saja bahwa ia adalah seorang hal itu dikarenakan informaninforman tersebut memikirkan akibat yang akan terjadi pada dirinya jika ia terlalu membuka statusnya.

Namun, menurut kelompok lesbian ada manfaat yang dihasilkan dari penerapan simbol-simbol signifikan terutama dari simbol bahasa melalui sebuah kata-kata. Dengan adanya simbol-simbol tersebut para informan dapat mengetahui orang lain yang termasuk juga seorang lesbian begitupun sebaliknya lesbian lain pun dapat mengetahui bahwa informan adalah seorang lesbian. Selain itu simbol-simbol tersebut juga menjaga privatisasi yang ada pada kelompok lesbian jika ada orang lain yang bukan lesbian berada di lingkungan mereka.

Dalam proses interaksi sosial, manusia secara simbolik mengkomunikasikan arti terhadap orang lain yang terlibat. Sebuah arti dari simbol yang disepakati tentunya mempunyai makna dan tujuan dikalangan kelompok lesbian tersebut. Beberapa informan dan kelompoknya memang menggunakan simbol-simbol tersebut secara umum agar dapat mengetahui siapa yang termasuk lesbian dan orang lain dapat mengetahuinya bahwa ia adalah lesbian tanpa harus memberitahukan secara langsung. Simbol yang disepakati kelompok-kelompok lesbian tersebut bertujuan agar orang lain yang mana bukan seorang lesbian tidak terlalu mengetahui identitas mereka.

Aktualisasi simbol pada kelompok pun yang mereka tunjukkan dengan cara kelompok tersebut berkumpul di tempat umum telah membuat interaksi kepada masyarakat. Beberapa informan sengaja memilih berkumpul di tempat umum dengan sengaja agar masyarakat mengetahui keberadaan mereka. Komunitas tersebut ingin masyarakat secara perlahan menerima keberadaan mereka. Bahkan ada komunitas dan LSM yang telah mengadakan suatu acara yang tentunya berhubungan dengan dunia lesbian. Namun, beberapa kelompok lesbian tidak bermaksud untul coming out namun hanya sebatas berkumpul biasa.

Perbedaan aktualisasi simbolik juga menimbulkan sedikit persaingan 
diantara beberapa kelompok lesbian. Beberapa kelompok lesbian tidak ingin masuk kedalam sebuah komunitas karena perbedaan prinsip yang ada yada pada kelompok dan begitupun sebaliknya.

\subsection{Bentuk Interaksi Kelompok Lesbian Dengan Masyarakat}

Masyarakat menempati posisi sentral dalam sebuah sistem. Pada tingkat kemasyarakatan (society) yang lebih khusus, Mead mempunyai sejumlah pemikiran tentang pranata sosial. Secara luas Mead mendefinisikan pranata sebagai tanggapan bersama dalam komunitas atau kebiasaan hidup komunitas. Secara lebih khusus, ia mengatakan bahwa keseluruhan tindakan komunitas tertuju pada individu berdasarkan keadaan tertentu menurut cara yang sama. Berdasarkan keadaan itu pula, terdapat respon yang sama di pihak komunitas.

Tidak mudah menunjukkan secara terbuka di masyarakat bahwa kelompok ataupun sebuah komunitas lesbian memang berada di sekitar mereka. Perlu cara dan tahap tersendiri untuk berinteraksi ke masyarakat bahwa lesbian memang ada dan sudah banyak aktornya. Dalam kebanyakan interaksi, aktor harus memperhatikan orang lain dan menentukan kapan dan bagaimana cara menyesuaikan aktifitasnya terhadap orang lain. Interaksi adalah proses dimana kemampuan berpikir dikembangkan dan diperlihatkan. Semua jenis interaksi tak hanya selama sosialisasi, namun juga memperbesar kemampuan kita untuk berpikir.

Semakin banyak terlihat aktualisasi simbolik pada kelompok lesbian ditempat umum tentunya menimbulkan dampak atau reaksi dari masyarakat yang peka terhadap keberadaannya namun masih belum menerima kehadiran mereka. Salah satu dari kelompok informan pernah mengalami disikriminasi dari masyarakat yang mana masyarakat tersebut menuntut komunitas mereka untuk datang kembali ke mall tempat berkumpulnya para lesbian tersebut. Informan lainpun mengalami hal yang sama seperti masyarakat yang melihat dengan tatapan sinis dan bisikan- bisikan tentang dirinya. Namun, para informan menganggap itu biasa karena mereka sadar bahwa itu memang sebuah resiko yang harus ditanggungnya.

\section{IV.SIMPULAN}

Dari hasil penelitian ini, peneliti menarik kesimpulan bahwa proses sesorang menjadi lesbian memiliki cara yang berbeda-beda. Terdapat beberapa macam proses seseorang menjadi lesbian, yaitu faktor genetik keluarga, pengalaman traumatik masa lalu dan kondisi keluarga yang terlalu membatasi dalam pergaulan.

Simbol interaksi kaum lesbian yang ditunjukkan melalui simbol-simbol signifikan non verbal terdapat pada seorang butchi dan terdapat variasi simbol diantara kelompok lesbian tersebut. Adapula simbol-simbol signifikan verbal seperti kata-kata dan sikap/perilaku. Simbol yang ditunjukkan sesuai dengan karakter lesbian yang ada pada diri mereka. Simbol-simbol tersebut mempunyai manfaat dan tujuan tersendiri yang merupakan bentuk dari perwujudan identitas diri mereka sebagai seorang lesbian. Simbol-simbol itu tentunya banyak digunakan di lingkup kelompok lesbian yang juga mengetahui 
simbol-simbol tersebut. Aktualisasi simbol tersebut juga ditunjukkan secara simbolik oleh kelompok dengan berkumpul di tempat umum sehingga terlihatnya aktualiasasi simbolik mereka tersebut menimbulkan problematika tersendiri di lingkup masyarakat umum.

\section{UCAPAN TERIMA KASIH}

Terima kasih kepada Universitas Airlangga yang telah memberi ilmu untuk menulis karya tulis ilmiah dan terima kasih kepada Pak Daniel Theodore Sparingga yang telah membantu saya menulis karya tulis ilmiah ini. Kepada rekan-rekan yang telah membantu diskusi dalam menyelesaikan karya ilmiah ini dan tidak lupa terima kasih kedua orang kedua orang tua yang telah mensupport baik material maupun non material.

\section{DAFTAR PUSTAKA}

Bagong, Suyanto, Sutina. 2006. Metode Penelitian Sosial Berbagai Alternatif Pendekatan. Jakarta: Prenada Media Group.

Craib, Ian. 2003. Teori-teori Sosial Modern: Dari Parson Sampai Habermas. Jakarta: Raja Grafindo Persada.

Idrus, Muhammad. 2007. Metode Penelitian Sosial. Yogyakarta: Erlangga.

Ritzer, George \& Douglash J Godman. 2014. Teori Sosiologi. Edisi kesepuluh. Yogyakarta: Kreasi Wacana.
Ritzer, George. 2012. Teori Sosiologi. Edisi Kedelapan. Yogyakarta: Pustaka Pelajar.

Spencer, Colin. 2004. Sejarah Homoseksualitas. Yogyakarta: Kreasi Wacana.

Budiarty, Asty. 2011. Gaya Hidup Lesbian (Studi Kasus di Kota Makassar).

Tarigan, Megawati. 2011. Komunikasi Interpersonal Kaum Lesbian di Kota Pontianak Kalimantan Barat. Yogyakarta.

Tjia, Regina Olivia. 2012. Perbedaan Proses Coming Out Antara Gay dan Lesbian. Jakarta.

Rusanti, Dyah Ayu Harfi. 2011. Negosiasi Identitas Lesbian Dalam Masyarakat Heterosexsual. Semarang.

Ardiyani, Mirza. 2010. Kontruksi Sosial Tentang Lesbian (Studi Kualitatif Tentang Makna Lesbian di k.langan Mahasiswa Lesbian di FISIP Universitas Airlangga). Skripsi. Universitas Airlangga, Surabaya.

Rusanti, Dian. 2010. Identitas Seorang Lesbian (Studi Deskriptif Tentang Pencitraan dan Identitas Diri Lesbian di Surabaya). Skripsi. Universitas Airlangga, Surabaya.

Puspasari, Ni Yoman Yuliana. 2012. Perkawinan Sepasang Lesbian ( Studi Deskriftif Tentang Makna Perkawinan Pada Komunitas Lesbian di Kota Surabaya). Skripsi. Universitas Airlangga, Surabaya. 